\title{
The Effect of Salicylates on the Hemostatic
}

\section{Properties of Platelets in Man}

\author{
Harvey J. Weiss, Louts M. Aledort, and Shaul Kochwa \\ From the Department of Medicine (Hematology), The Mount Sinai Hospital \\ and School of Medicine of the City University of New York, New York 10029 \\ and The City Hospital at Elmhurst, New York 11373
}

A B S T R A C T Ingestion of $1.5 \mathrm{~g}$ of aspirin, but not of sodium salicylate, produced a significant prolongation of the bleeding time in six normal male subjects when compared with the effects of a placebo. Similar differences in the effect of the two drugs on platelets was also observed. Aspirin ingestion resulted in impaired platelet aggregation by connective tissue and was associated with a decreased release of platelet adenosine diphosphate (ADP) ; sodium salicylate had no effect on these values. In vitro, incubation of platelet-rich plasma with an optimum aspirin concentration of $0.50 \mathrm{mmole} /$ liter $(0.045 \mathrm{mg} / \mathrm{ml})$ inhibited both the adhesion of platelets to connective tissue and the release of ADP as well as the secondary wave of platelet aggregation produced with ADP or epinephrine; sodium salicylate had no effect on these reactions, which were also normal in patients with von Willebrand's disease. The inhibitory effect produced by ingesting a single $1.8 \mathrm{~g}$ dose of aspirin was detectable for 4-7 days at which time salicylate was no longer detectable in the blood, which suggested an irreversible effect on the platelet. Aspirin also inhibited the release of platelet adenosine triphosphate (ATP), but had no effect on the platelet surface charge, available platelet ATP or ADP, or the destruction of ADP by plasma ADPase. These studies lend further support to the hypothesis that ingestion of aspirin, in contrast to sodium salicylate, prolongs the bleeding time by inhibiting the release of platelet

An abstract of some of the material presented here has been previously reported in J. Clin. Invest. 1968. 47: 101 a.

Received for publication 1 April 1968 and in revised form 29 May 1968.
ADP, perhaps reflecting the findings in other cell systems which suggest that aspirin alters membrane permeability.

\section{INTRODUCTION}

Ingestion of aspirin (acetylsalicylic acid) in doses of the order of $3 \mathrm{~g}$ daily for 2-3 days has been shown to produce occult gastrointestinal bleeding in $70 \%$ of normal subjects (1-3). Although the average daily loss in these subjects was usually 3-5 ml, measured by the radiochromium technique, losses of 14-18 ml were seen in some subjects. Aspirin ingestion has been reported to be a precipitating factor in $50 \%$ of patients with overt gastrointestinal hemorrhage (4) and its chronic use has been implicated as a cause of iron deficiency anemia (5). The above findings are probably unrelated to the prothrombinemic effects of very large doses of aspirin since Quick and Clesceri have shown that, in man, ingestion of as much as $6 \mathrm{~g}$ daily for 6 days only prolongs the prothrombin time by an average of $2 \mathrm{sec}$ (6), while Meyer and Howard reported that ingestion of $5.3 \mathrm{~g}$ daily for 3-11 days resulted in an increase of $1-4.5 \mathrm{sec}$ (7). Although the hemorrhagic effect of aspirin has been attributed to gastrointestinal irritation $(8,9)$, it has also been observed after intravenous administration (10), suggesting a systemic effect on hemostasis. Supporting evidence was provided by the findings of Blatrix (11) and Quick (12) that the bleeding time often increased in normal subjects after aspirin ingestion. Quick also reported that this effect was more pronounced in patients with von Wille- 
brand's disease and suggested that the effect of aspirin was to decrease the plasma "anti-bleeding" factor lacking in this disorder (13). Our recently reported studies suggest a different mechanism (14). In 10 normal male subjects, ingestion of $3 \mathrm{~g}$ of aspirin daily for 2.25 days resulted in decreased platelet aggregation by connective tissue. Further studies demonstrated that this was due to impairment in the release of platelet adenosine diphosphate (ADP), although primary aggregation by ADP itself was unchanged. This abnormality is similar to the findings recently reported by Weiss (15) and, independently, by Hardisty and Hutton (16) in a group of patients with prolonged bleeding time and normal antihemophilic globulin (AHG) values, whose condition we have called thrombopathia. By contrast, in nine patients who showed the findings of a prolonged bleeding time and decreased AHG values characteristic of classical von Willebrand's disease, both platelet aggregation by connective tissue and ADP release were normal.

Quick has reported that sodium salicylate, unlike aspirin, has no effect on the bleeding time (12). To be consistent with our hypothesis regarding the nature of the hemostatic defect produced by aspirin, the ingestion of sodium salicylate should have no, or a lesser, effect on the platelet-connective tissue reaction. The purpose of this study was to test this hypothesis and to further explore the nature of the hemostatic defect produced by aspirin.

\section{METHODS}

Platelet-rich plasma. Blood was collected $(9: 1)$ in either $3.2 \%$ sodium citrate or $1 \%$ sodium ethylenediaminetetracetate (EDTA) in $0.7 \%$ saline and then centrifuged at $2500 \mathrm{rpm}$ and $20^{\circ} \mathrm{C}$ for $3 \mathrm{~min}$ to obtain platelet-rich plasma (PRP) which contained $350,000-600,000$ platelets/ $\mathrm{mm}^{3}$, counted by phase microscopy. All glassware was siliconized. ${ }^{1}$

Salicylates and buffer solutions. Powdered aspirin (acetylsalicylic acid) and sodium salicylate, obtained from the Merck Pharmaceutical Company, were used for both in vivo and in vitro studies. For in vitro studies, a stock $50 \mathrm{~mm}$ solution was prepared daily by dissolving either $900 \mathrm{mg}$ of aspirin or $800 \mathrm{mg}$ of sodium salicylate in $100 \mathrm{ml}$ containing $0.125 \mathrm{M}$ imidazole and adjusting the final $\mathrm{pH}$ to $7.35 \pm 0.05$. The standard buffer used for preparing all dilutions and as a control in the in vitro experiments was $0.05^{\circ} \mathrm{M}$ imidazole in saline, $\mathrm{pH}=7.3$, ionic strength $=0.13$ (imidazole-buffered saline, IBS).

${ }^{1}$ General Electric SC-87 DRI-FILM, 15\% in toluene.
Platelet aggregation and ADP release were studied by a turbidometric method, as previously described (15, 17). In essence, when citrated PRP is stirred with connective tissue, $\mathrm{ADP}$, or epinephrine in the cuvette $0_{\text {: }}$ an Evans titrator (Sales Associates, Langhorne, $\mathrm{Pa}$.) the formation of platelet aggregates results in a progressive increase in light transmittance, relative to a platelet-poor plasma blank. Aggregation by connective tissue was studied at ambient temperature by stirring $2.6 \mathrm{ml}$ of PRP with either $0.10 \mathrm{ml}$ or $0.05 \mathrm{ml}$ of connective tissue suspension for $6 \mathrm{~min}$ and recording the change in transmission automatically on a Bausch and Lomb VOM-6 recorder. The initial (I) and final (F) transmittance readings were converted to optical density (OD) and the per cent platelet aggregation defined as :

$$
\frac{[\mathrm{OD}]_{\mathrm{I}}-[\mathrm{OD}]_{\mathrm{F}}}{[\mathrm{OD}]_{\mathrm{I}}} \times 100 .
$$

The aggregates were immediately removed by centrifugation for $5 \mathrm{~min}$ and the supernatant plasma immediately frozen in a mixture of $\mathrm{CO}_{2}$-acetone and then stored at $-50^{\circ} \mathrm{C}$ until assayed for $\mathrm{ADP}$, as described below (released ADP). The number of residual platelets present in the supernatant plasma, as determined in several experiments, was $3000-5000 / \mathrm{mm}^{3}$ and was not significantly altered by previous incubation of the PRP with salicylates. The preparation of the connective tissue suspension used for these experiments was similar to the method described by Zucker and Borrelli (18). Human subcutaneous tissue was obtained from surgical specimens removed during radical mastectomy and washed three times in an equal volume of cold isotonic saline. To prepare the extracts, $200 \mathrm{~g}$ of washed tissue were homogenized, at high speed, with $400 \mathrm{ml}$ of cold saline for $3 \mathrm{~min}$ in a Waring Blendor. After centrifuging the homogenate for $20 \mathrm{~min}$ at $3000 \mathrm{rpm}$ in an International PR-2 centrifuge, we discarded the lower third layer, containing the larger sedimented fragments, and the upper fat-containing third layer. The turbid middle layer (concentrated connective tissue extract) contained $6.8 \mu \mathrm{g}$ of hydroxyproline per ml, determined by the method of Hutterer and Singer (19), and $0.094 \%$ protein, measured with Folin reagent (20) after hydrolysis in $2.5 \mathrm{~N} \mathrm{NaOH}$. The extracts used to test platelet aggregation were prepared by diluting the concentrated suspension $1: 5$ in saline, frozen in aliquots at $-50^{\circ} \mathrm{C}$, and thawed on the day used. When stored in this manner, the extracts used for this study have retained their original aggregating activity, estimated by periodic testing of normal PRP, for at least 9 months.

Platelet aggregation by ADP (sodium ADP, Sigma Chemical Company, St. Louis, Mo.) and epinephrine (adrenaline chloride, Parke, Davis \& Company, Detroit, Mich.) was studied at $37^{\circ} \mathrm{C}$.

Adhesion of platelets to connective tissue. The connective tissue-saline suspension used for this experiment was a $1: 3$ dilution of the concentrated suspension, described above. $2 \mathrm{ml}$ of EDTA PRP was stirred in the Evans cuvette with $0.1 \mathrm{ml}$ of either buffer or salicylate for $1 \mathrm{~min}$ at which time $0.4 \mathrm{ml}$ of connective tissue suspension was added. The mixture was then stirred for 1 
more min and the number of single platelets then counted by phase microscopy. Adhesion of platelets resulted in the formation of connective tissue-platelet aggregates, which were easily identifiable. Although ADP was released from the platelets during the procedure, it does not cause aggregation in EDTA PRP (21) as verified in separate experiments. Thus, in the absence of adhesion, the number of single (nonadherent) platelets counted should be the same as in a control specimen obtained by stirring $2.0 \mathrm{ml}$ of PRP $+0.1 \mathrm{ml}$ of buffer $+0.4 \mathrm{ml}$ of saline. The actual number of adherent platelets is determined from the difference in the two counts.

Platelet nucleotides were assayed in either citrated PRP or in the supernatant plasma containing released ADP (see above). ATP was determined by the method of firefly luminescense previously described (22) and the results were expressed as m $\mu$ moles of ATP per $10^{\circ}$ platelets. ADP was assayed by modifying the Boehringer enzymatic method for determining ADP in whole blood. ${ }^{2}$ Plasma was mixed with an equal volume of $4 \% \mathrm{HClO}$ for $10 \mathrm{~min}$ and then centrifuged. The deproteinized supernatant was then added to volume of $0.8 \mathrm{M}$ Tris, $^{8}$ adjusted to $\mathrm{pH} 9.82$ with $\mathrm{HCl}$, containing $1 \mathrm{M} \mathrm{K}_{2} \mathrm{CO}_{3}$ and placed in an ice bath for $15 \mathrm{~min}$. The precipitated $\mathrm{KClO}$, was removed by centrifugation and the supernatant, whose $\mathrm{pH}$ was now 7.5 \pm 0.1 , assayed for ADP. The method utilized the following reactions:

$$
\begin{gathered}
\text { ADP }+ \text { phosphoenolpyruvate }(\mathrm{PEP}) \underset{\begin{array}{c}
\text { pyruvate kinase }(\mathrm{PK}) \\
\text { ATP }+ \text { pyruvate }
\end{array}}{\text { pyruvate }+\mathrm{NADH}+\mathrm{H}^{+} \underset{\text { lactic dehydrogenase (LDH) }}{\longrightarrow}} \text { lactate }+ \text { NAD }
\end{gathered}
$$

To perform the assay, we mixed $2.0 \mathrm{ml}$ of test supernatant in a cuvette with $0.15 \mathrm{ml}$ of $0.01 \mathrm{M} \mathrm{PEP}, 0.10 \mathrm{ml}$ of $0.009 \mathrm{M} \mathrm{NADH}$ and $0.02 \mathrm{ml}$ of $\mathrm{LDH}(1 \mathrm{mg} / \mathrm{ml})$ for $5 \mathrm{~min} .0 .02 \mathrm{ml}$ of $\mathrm{PK}(1 \mathrm{mg} / \mathrm{ml})$ was then added and the change in $O D$ at $340 \mathrm{~m} \mu$ after $5 \mathrm{~min}$, due to removal of NADH, was determined with a Beckman Spectrophotometer. A calibration curve was prepared by performing the assay on platelet-poor plasma to which known amounts of ADP were added. ADP was also assayed as platelet aggregating equivalent, as previously described (15, 17).

Platelet electrophoretic mobility was determined by microelectrophoresis, using a Zeiss cytophorometer. Studies were performed using citrated PRP diluted $1: 20$ in IBS or, as described in Results, in the same buffer containing $0.5 \mathrm{~mm}$ salicylate. The timed migration of 20 separate platelets was determined in each direction. The mean migration time and SD were determined and the electrophoretic mobility calculated as :

$$
\mu=\frac{l h a}{t J \rho} \quad\left[\mathrm{cm}^{2} \sec ^{-1} \mathrm{v}^{-1}\right]
$$

where $l=$ distance travelled in $\mathrm{cm} ; h=$ height of the cell

2 C. F. Boehringer, Mannheim, Germany.

3 Tris (Hydroxymethyl) amino methane, Fisher Scientific Company, Pittsburgh, Pa. in $\mathrm{cm} ; a=$ depth of the cell in $\mathrm{cm} ; t=$ time in sec; $J=$ current in amperes; $\rho=$ specific resistance in $\Omega \mathrm{cm}$.

Total serum salicylate concentration was determined by the method of Brodie, Udenfriend, and Coburn in which the color developed by the addition of $0.5 \mathrm{ml}$ of serum to $4.5 \mathrm{ml}$ of solution containing $5.56 \mathrm{~g}$ of $\mathrm{Fe}\left(\mathrm{NO}_{3}\right)$. $9 \mathrm{H}_{2} \mathrm{O}$ per liter of $0.038 \mathrm{~N} \mathrm{HNO}_{3}$ is read against a serum $+\mathrm{HNO}_{3}$ blank at $540 \mathrm{~m} \mu$ (23). Normal serum, free of salicylate, gives a detectable reading with the ferric reagent, so that for each subject, the reading obtained with his salicylate-free serum was subtracted from that of the specimen obtained after salicylate ingestion. Calibration curves were obtained by adding known amounts of salicylate to normal serum and the results expressed as milligrams of free salicylate per milliliter. Sera were obtairfed from blood which had been clotted for $3 \mathrm{hr}$ at $37^{\circ} \mathrm{C}$ and were frozen at $-20^{\circ} \mathrm{C}$ until tested. They were further incubated, on the day tested, for $3 \mathrm{hr}$ at $45^{\circ} \mathrm{C}$ to ensure complete hydrolysis of any remaining acetylsalicylic acid, which is not measured by the Brodie method.

Subjects. (a) Comparative effects of aspirin and sodium salicylate. $2 \mathrm{hr}$ after a light, fat-free breakfast, six normal male subjects, ages 20-35, ingested five capsules of identical appearance each containing $0.3 \mathrm{~g}$ of either aspirin, sodium salicylate, or a lactose placebo. Blood was obtained before and $2 \mathrm{hr}$ after drug ingestion and centrifuged to obtain citrated PRP. Platelet aggregation was studied $90 \pm 10 \mathrm{~min}$ after venipuncture by stirring $2.6 \mathrm{ml}$ of PRP with $0.10 \mathrm{ml}$ of connective tissue suspension for $6 \mathrm{~min}$ and the amount of ADP released determined, as described above. Aggregation was also studied $150 \pm 10 \mathrm{~min}$ after venipuncture by stirring $2.6 \mathrm{ml}$ of PRP with $0.05 \mathrm{ml}$ of connective tissue; however ADP release was not determined. Bleeding time was performed in duplicate, before and $2 \mathrm{hr}$ after drug ingestion, on a 3 $\mathrm{mm}$ deep puncture wound made with a No. 11 Bard Parker Blade (Ivy method). The study was conducted by the double blind technique on 3 days separated by 2 wk and was arranged so that on each day paired subjects received a different drug and at the end of the study each subject had received aspirin, sodium salicylate, and the placebo.

(b) Other studies-the duration of the aspirin induced platelet defect and the effect of aspirin ingestion on platelet nucleotides were determined in separate experiments, with normal male subjects.

Statistical methods. Results were analyzed by Student's $t$ test and by analysis of variance for a mixed model (24).

\section{RESULTS}

Comparative effects produced by aspirin and sodium salicylate

\section{In Vivo Studies (Table I)}

Normal male subjects ingested aspirin, sodium salicylate, or a placebo, as described in methods. 
TABLE I

Effects of Drug Ingestion

\begin{tabular}{|c|c|c|c|c|c|c|c|c|c|c|c|c|c|c|}
\hline \multirow[b]{3}{*}{ Drug } & \multirow{3}{*}{$\begin{array}{l}\text { Sub- } \\
\text { ject } \\
\text { No. }\end{array}$} & \multirow{3}{*}{$\underset{\text { Salicylate* }}{\text { Serum }}$} & \multirow{2}{*}{\multicolumn{3}{|c|}{ Bleeding time }} & \multirow{2}{*}{\multicolumn{3}{|c|}{$\begin{array}{l}\text { Release of platelet } \\
\text { ADP } \ddagger \text { by } 0.1 \mathrm{ml} \mathrm{CT}\end{array}$}} & \multicolumn{6}{|c|}{ Platelet aggregation by connective tissue } \\
\hline & & & & & & & & & \multicolumn{3}{|c|}{$0.10 \mathrm{ml} \mathrm{CT}$} & \multicolumn{3}{|c|}{$0.05 \mathrm{ml} \mathrm{CT}$} \\
\hline & & & B & A & D & B & A & D & B & A & $\mathrm{D}$ & B & A & D \\
\hline & & $m g / m l$ & & $\min$ & & & mumol & $s / 10^{\circ}$ & & & & & & \\
\hline \multirow[t]{6}{*}{ Placebo } & 1 & & 2.5 & 3.5 & +1 & 14 & 21 & +7 & 74 & 77 & +3 & 54 & 67 & +13 \\
\hline & 2 & & 3 & 2.5 & -0.5 & 18 & 17 & -1 & 63 & 81 & +18 & 61 & 77 & +16 \\
\hline & 3 & & 2 & 2 & 0 & 16 & 17 & +1 & 76 & 74 & -2 & 66 & 74 & +8 \\
\hline & 4 & & 3.5 & 3.0 & -0.5 & 7 & 16 & +9 & 80 & 81 & +1 & 76 & 79 & +3 \\
\hline & 5 & & 5 & 3 & -2 & 15 & 9 & -6 & 84 & 77 & -7 & 49 & 50 & +1 \\
\hline & 6 & & 2 & 3 & +1 & 14 & 14 & 0 & 78 & 78 & 0 & 62 & 72 & +10 \\
\hline $\begin{array}{l}\text { Mean } \\
\text { SE }\end{array}$ & & & & & $\begin{array}{r}-0.17 \\
0.46\end{array}$ & & & $\begin{array}{r}+1.67 \\
2.24\end{array}$ & & & $\begin{array}{r}+2.2 \\
3.4\end{array}$ & & & $\begin{array}{r}+8.5 \\
2.3\end{array}$ \\
\hline \multirow[t]{6}{*}{ Aspirin } & 1 & 0.140 & 2 & 4.5 & +2.5 & 18 & 3 & -15 & 80 & 64 & -16 & 80 & 43 & -37 \\
\hline & 2 & 0.127 & 3 & 6 & +3 & 14 & 6 & -8 & 61 & 77 & +16 & 67 & 67 & 0 \\
\hline & 3 & 0.132 & 2 & 2.5 & +0.5 & 21 & 5 & -16 & 73 & 71 & -2 & 65 & 66 & +1 \\
\hline & 4 & 0.064 & 5 & 6 & +1 & 5 & 5 & 0 & 63 & 63 & 0 & 46 & 45 & -1 \\
\hline & 5 & 0.110 & 3.5 & 5.5 & +2 & 13 & 2 & -11 & 84 & 76 & -8 & 81 & 44 & -37 \\
\hline & 6 & 0.103 & 1 & 2.5 & +1.5 & 19 & 4 & -15 & 72 & 50 & -22 & 83 & 46 & -37 \\
\hline Mean & & 0.113 & & & +1.75 & & & -10.8 & & & -5.3 & & & -18.5 \\
\hline SE & & 0.011 & & & 0.4 & & & 2.5 & & & 5.4 & & & 8.2 \\
\hline \multirow{6}{*}{$\begin{array}{l}\text { Sodium } \\
\text { salicylate }\end{array}$} & 1 & 0.117 & 3 & 2 & -1 & 13 & 24 & +11 & 82 & 70 & -12 & 67 & 71 & +4 \\
\hline & 2 & 0.100 & 2.5 & 2 & -0.5 & 18 & 21 & +3 & 74 & 81 & +7 & 75 & 65 & -10 \\
\hline & 3 & 0.123 & 2 & 2 & 0 & 9 & 7 & -2 & 71 & 69 & -2 & 78 & 69 & -9 \\
\hline & 4 & 0.110 & 3.5 & 3.0 & -0.5 & 8 & 9 & +1 & 82 & 82 & 0 & 74 & 90 & +16 \\
\hline & 5 & 0.089 & 3 & 2.5 & -0.5 & 18 & 11 & -7 & 80 & 80 & 0 & 74 & 81 & +7 \\
\hline & 6 & 0.087 & 3 & 1.5 & -1.5 & 10 & 10 & 0 & 82 & 92 & +10 & 74 & 84 & +10 \\
\hline \multirow{2}{*}{\multicolumn{2}{|c|}{$\begin{array}{l}\text { Mean } \\
\text { SE }\end{array}$}} & 0.104 & & & -0.6 & & & +1.0 & & & +0.5 & & & +3.0 \\
\hline & & 0.006 & & & 0.3 & & & 2.4 & & & 3.1 & & & 4.3 \\
\hline \multicolumn{15}{|c|}{$P$ values for $\mathrm{D}$} \\
\hline \multicolumn{3}{|c|}{ Aspirin vs. placebo } & & & $<0.01$ & & & $<0.01$ & & & $<0.10$ & & & 0.01 \\
\hline \multicolumn{3}{|c|}{ Aspirin vs. Na salicylate } & & & $<0.001$ & & & $<0.01$ & & & $>0.10$ & & & $<0.05$ \\
\hline
\end{tabular}

B, before drug; A, after drug; D, B-A; CT, connective tissue.

* As free salicylate, after hydrolysis, $2 \mathrm{hr}$ after ingestion.

$\ddagger$ Platelet aggregating equivalent.

After aspirin ingestion, the Ivy bleeding time increased by $+1.75 \pm 0.4$ (SE) min, compared with a change of $-0.17 \pm 0.46 \mathrm{~min}$ observed after ingestion of the placebo $(P<0.01)$. By contrast, the change of $-0.6 \pm 0.3 \mathrm{~min}$ obtained after ingestion of sodium salicylate was not significant, confirming Quick's observations.

Aspirin ingestion resulted in decreased platelet aggregation by connective tissue, although the results were only significant, when compared with the effects of the placebo, with the lower concentration of connective tissue. Aggregation decreased by $-18.5 \pm 8.2 \%$ after aspirin ingestion $(P=$
$0.01)$, compared with a change of $+3.0 \pm 4.3 \%$ after sodium salicylate and $+8.5 \pm 2.3 \%$ after the placebo. The amount of ADP released by connective tissue decreased by $-10.8 \pm 2.5$ (SE) $\mathrm{m} \mu$ moles $/ 10^{\circ}$ platelets after aspirin ingestion, compared with a change of $+1.67 \pm 2.24$ after ingesting the placebo $(P<0.01)$; the change of $+1.0 \pm 2.4$ obtained with sodium salicylate was not significant.

Analysis of variance (Table II) indicated that ingestion of sodium salicylate did not significantly alter either the Ivy bleeding time, platelet aggregation, or ADP release, when compared with the 
TABLE II

Comparative Effects of Drug Ingestion on Measured Values: Analysis of Variance

\begin{tabular}{|c|c|c|c|c|c|c|c|c|c|c|c|c|c|}
\hline \multirow[b]{3}{*}{ Source of variation } & \multirow[b]{3}{*}{ D.F. } & \multirow{2}{*}{\multicolumn{3}{|c|}{ Ivy bleeding time, sec }} & \multirow{2}{*}{\multicolumn{3}{|c|}{$\begin{array}{l}\text { Release of platelet ADP } \\
\text { by } 0.1 \mathrm{ml} \mathrm{CT} \text {, } \\
\text { m } \mu \text { moles } / 10^{\circ} \text { platelets }\end{array}$}} & \multicolumn{6}{|c|}{ Platelet aggregation by $\mathrm{CT}, \%$} \\
\hline & & & & & & & & \multicolumn{3}{|c|}{$0.1 \mathrm{ml} \mathrm{CT}$} & \multicolumn{3}{|c|}{$0.05 \mathrm{ml} \mathrm{CT}$} \\
\hline & & S.S. & M.S. & $\mathbf{F}$ & S.S. & M.S. & $\mathbf{F}$ & S.S. & M.S. & $\mathbf{F}$ & S.S. & M.S. & $\mathbf{F}$ \\
\hline $\begin{array}{l}\text { Na salicylate vs. placebo } \\
\text { Aspirin vs. Na salicylate }\end{array}$ & 1 & 0.52 & 0.52 & 0.51 & 1.3 & 1.3 & 0.024 & 8.3 & 8.3 & 0.10 & 91 & 91 & 0.40 \\
\hline +placebo & 1 & 17.72 & 17.72 & $17.54 \ddagger$ & 592.4 & 592.4 & $23.7 \S$ & 177.7 & 177.7 & 2.26 & 2352 & 2352 & $10.5 \ddagger$ \\
\hline Subjects & 5 & 2.31 & 0.46 & 0.45 & 266 & 53.2 & 2.12 & 761.8 & 152.3 & 1.93 & 532 & 106 & 0.48 \\
\hline Interaction (error) & 10 & 10.11 & 1.01 & - & 250 & 25.0 & - & 785.9 & 78.6 & - & 2237 & 223.7 & 一 \\
\hline
\end{tabular}

* CT, connective tissue.

$\ddagger P<0.01$.

$\& P<0.001$.

effects of the placebo. When the effects of aspirin ingestion were compared with those of the placebo and sodium salicylate, significant changes were observed for all these values.

\section{In Vitro StUdies}

Reactions of platelets to connective tissue. The differences between the effects of aspirin and sodium salicylate were demonstrable in vitro. Citrated PRP from normal subjects was incubated for $10 \mathrm{~min}$ with $1 / 20$ volume of salicylates and then stirred with connective tissue for $6 \mathrm{~min}$. As seen in Fig. 1, incubation with aspirin, in an

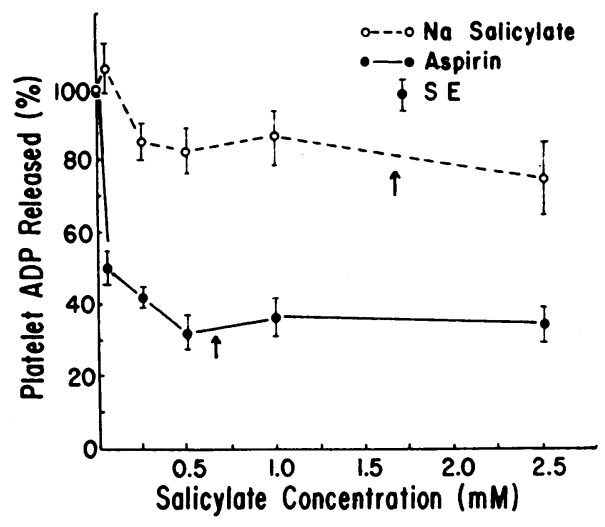

FIGURE 1 Effect on aspirin and sodium salicylate in vitro. Platelet-rich plasma (PRP) from four normal subjects was incubated with salicylate in the final concentration shown and then $2.6 \mathrm{ml}$ was stirred with 0.10 $\mathrm{ml}$ of connective tissue suspension for $6 \mathrm{~min}$. The amount of ADP released was expressed as a percentage of the ADP released in the control specimen (PRP incubated with buffer). Arrows ( $\uparrow$ ) indicate the concentration of total salicylate at which the concentration of nonproteinbound salicylate would be $0.45 \mathrm{mmole} / \mathrm{liter}$, estimated from data presented elsewhere (39) (see Discussion). optimal concentration of $0.50 \mathrm{mmole} / \mathrm{liter}$, resulted in a $70 \%$ inhibition in the release of platelet ADP; with sodium salicylate, only a $20 \%$ inhibition was achieved.

Aspirin also inhibited the adhesion of platelets to connective tissue, while sodium salicylate did not. The studies were performed as described in Methods on PRP from seven different normal subjects and two separate determinations were made for each salicylate and for IBS. The results, shown in Table III, demonstrate that in the presence of aspirin, the per cent of adhesive platelets was $16.4 \pm 4.52^{4}$ compared with values of 23.3 \pm 4.52 and $26.6 \pm 3.12$ obtained with IBS and sodium salicylate. Analysis of variance indicates a significant difference between the effect of aspirin and that of sodium salicylate and the buffer.

Platelet aggregation by ADP and epinephrine. When citrated PRP is stirred with epinephrine or $\mathrm{ADP}$ at $37^{\circ} \mathrm{C}$, in contrast to ambient temperature, platelet aggregation occurs in two waves (Fig. 2).

$$
42 \mathrm{SE} \text {. }
$$

TABLE III

Effect of Salicylates on the Adhesion of Platelets to Connective Tissue

\begin{tabular}{cclrrrr}
\hline \multicolumn{1}{c}{ Drug* } & $\begin{array}{c}\text { Adhesive } \\
\text { platelets }\end{array}$ & Analysis of variance & D.F. M.S. "F" \\
\hline & $\%+2 \mathrm{SE}$ & & & & \\
Buffer (B) & $23.3 \pm 4.52$ & Na Sal. vs. B & 1 & 116 & 1.90 \\
& & ASA vs. Na Sal. $\mathrm{B}$ & 1 & 624 & $10.2 \ddagger$ \\
Na salicylate & $26.6 \pm 3.12$ & Subjects & 6 & 102 & 1.67 \\
& & Interaction (error) & 12 & 61 & - \\
Aspirin (ASA) & $16.4 \pm 3.42 \S$ & Duplicates & 21 & 27 & - \\
\hline
\end{tabular}

* Salicylate $(0.5$ mmole/liter $)$ or buffer added to EDTA platelet richplasma from seven subjects. $\ddagger P<0.01$.

$\$ P<0.05$. 


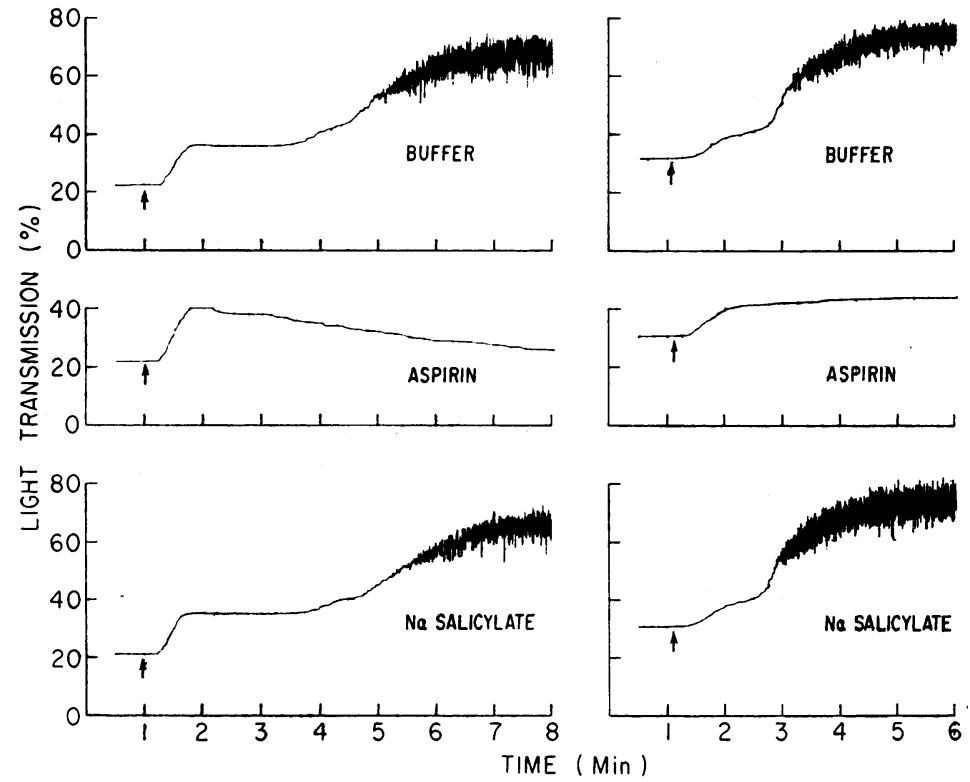

FIgURE 2 Platelet aggregation by epinephrine and $\mathrm{ADP}$ at $37^{\circ} \mathrm{C}$. Citrated PRP from a normal subject was incubated for $5 \mathrm{~min}$ with $1 / 20$ volume of buffer or salicylate in final concentration of 0.5 mmole/liter. Arrows ( $\uparrow)$ indicate the addition of ADP ( $1.5 \mu$ moles/liter) or epinephrine ( $5 \mu$ moles/liter).
MacMillan has shown that the first is caused by the agent added, while the second is caused by release of intrinsic platelet ADP (25). As may be seen, previous incubation of the PRP with aspirin inhibits the second, but not the first, phase of aggregation, as also observed by Zucker and Peterson after aspirin ingestion (26). By contrast, incubation with sodium salicylate has no effect on either phase. In a patient with classical von Willebrand's disease whose AHG concentration was $4 \%$ and whose bleeding time was longer than $30 \mathrm{~min}$, a prominent secondary phase of platelet aggregation was obtained with both ADP and epinephrine.

Further studies on the aspirin induced defect

Duration of the platelet defect produced by aspirin ingestion. Base line values of platelet ADP release by connective tissue were obtained on 5 days for two normal subjects and the studies then repeated after ingestion of $1.8 \mathrm{~g}$ of aspirin. As seen in Fig. 3, a decrease in ADP release, compared with control values, was observed when first studied $2 \mathrm{hr}$ after drug ingestion. The abnormality per-

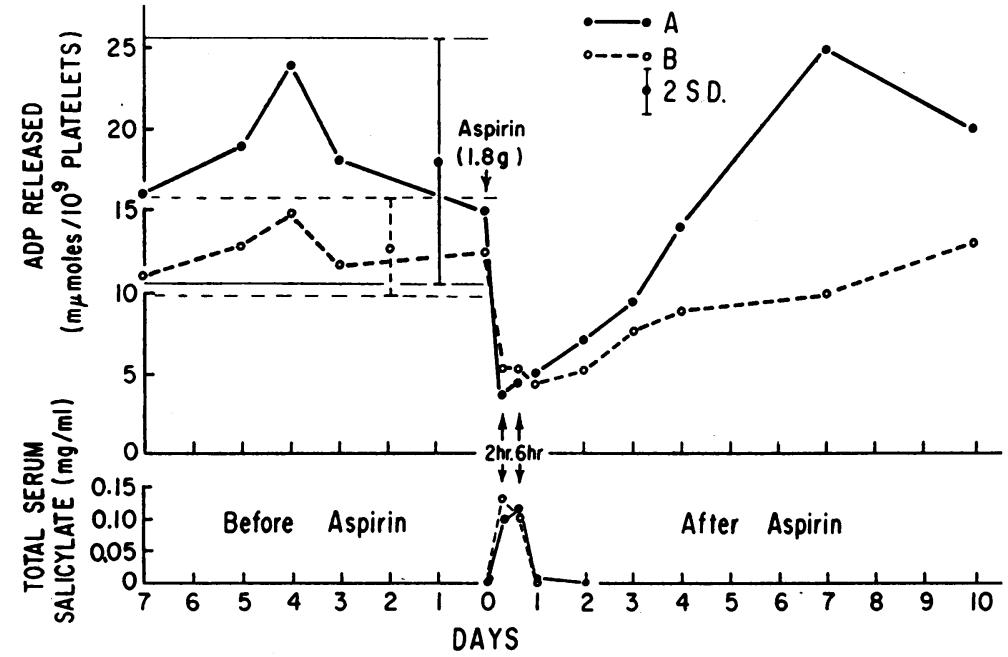

2174
FIGURE 3 Duration of the aspirin-induced platelet defect. The amount of ADP released when $2.6 \mathrm{ml}$ of citrated PRP was stirred with $0.1 \mathrm{ml}$ of connective tissue suspension was determined in two normal subjects ( $A$ and $B)$. The mean \pm 2 sD values obtained on 5 days before aspirin ingestion are indicated for each subject. 
sisted on the 2nd and 3rd day, at a time when salicylate was no longer detectable in the subject's blood, and did not completely disappear until 4-7 days after aspirin ingestion. Thus, the defect produced by aspirin occurred rapidly and persisted for a period roughly equal to the platelet life span, suggesting an irreversible effect on the platelet.

Optimal aspirin concentration. When $2.6 \mathrm{ml}$ of platelet-rich plasma from four normal subjects was stirred with $0.10 \mathrm{ml}$ of connective tissue suspension, the concentration of aspirin required to produce the maximum inhibition of platelet ADP release was 0.5 mmole/liter, as described above and shown in Fig. 1. Studies were performed to determine if larger amounts of connective tissue would require a higher concentration of aspirin to produce the maximum inhibitory effect. As seen in Fig. 4, with larger amounts of connective tissue, the inhibitory effect of aspirin lessened; however, the maximum effect was achieved at the same concentration of aspirin, in this subject 0.25 mmole/liter, for each of the concentrations of connective tissue used.

Platelet nucleotides. Studies were performed to determine if the inhibition of platelet ADP release produced by aspirin was associated with any change in the concentration of platelet nucleotides. The results obtained in three normal sub-

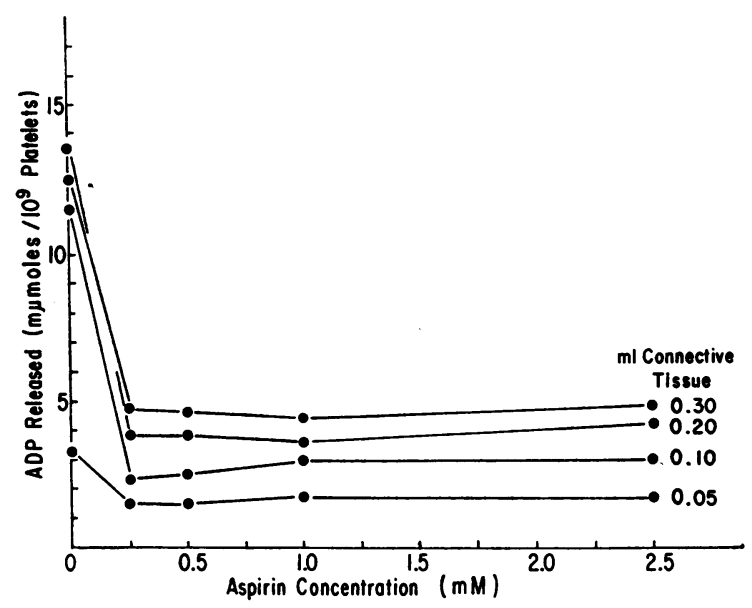

FIGURE 4 Effect of varying both the aspirin and connective tissue concentration on platelet ADP release. Citrated platelet-rich plasma from a normal subject was incubated for $10 \mathrm{~min}$ with the concentration of aspirin shown and $2.6 \mathrm{ml}$ of the mixture then stirred with the amount of connective tissue shown for $6 \mathrm{~min}$. A concentration of $1 \mathrm{mmole} /$ liter is equivalent to $0.09 \mathrm{mg} / \mathrm{ml}$.
TABLE IV

Effect of Aspirin Ingestion on Total Platelet Nucleotides and on the Amount of ADP Released by Connective Tissue*

\begin{tabular}{|c|c|c|c|c|c|c|}
\hline \multirow[b]{2}{*}{ Subject } & & \multicolumn{2}{|c|}{ ADP released $\ddagger$} & \multicolumn{2}{|c|}{$\begin{array}{l}\text { Total nu- } \\
\text { cleotides }\end{array}$} & \multirow[b]{2}{*}{$\begin{array}{c}\text { Ratio } \\
\text { ATP/ADP }\end{array}$} \\
\hline & & PAE & $\begin{array}{l}\text { Enzy- } \\
\text { matic }\end{array}$ & $\begin{array}{l}\text { ADP } \\
\text { Enzy- } \\
\text { matic }\end{array}$ & ATP & \\
\hline \multirow[t]{2}{*}{ I } & Before & 18.6 & 26.2 & 52 & 74 & 1.42 \\
\hline & After & 7.5 & 11.6 & 54 & 69 & 1.27 \\
\hline \multirow[t]{2}{*}{ II } & Before & 13.8 & 10.8 & 32 & 63 & 1.97 \\
\hline & After & 2.4 & 1.4 & 38 & 70 & 1.84 \\
\hline \multirow[t]{2}{*}{ III } & Before & 21.9 & 26.8 & 52 & 89 & 1.70 \\
\hline & After & 6.1 & 0 & 42 & 72 & 1.71 \\
\hline
\end{tabular}

* Studies were performed on citrated PRP before and $2 \mathrm{hr}$ after ingesting $1.5 \mathrm{~g}$ of aspirin and results expressed as $\mathrm{m} \mu \mathrm{moles} / 10^{\circ}$ platelets. ‡ A $2.6 \mathrm{ml}$ aliquot of PRP was stirred with $0.10 \mathrm{ml}$ of connective tissue for $6 \mathrm{~min}$ and the amount of ADP released assayed either enzymatically or as platelet aggregating equivalent (PAE).

jects who ingested $1.5 \mathrm{~g}$ of aspirin are shown in Table IV. As in previous experiments, aspirin ingestion resulted in a decreased release of platelet ADP, assayed either enzymatically or as platelet aggregating equivalent. Despite the decrease in ADP release, there was no significant change in the concentration of platelet ATP or ADP. In other in vitro experiments, it was found that aspirin also inhibited the release of platelet ATP. Citrated PRP from four normal subjects was incubated with either buffer or $0.5 \mathrm{mM}$ aspirin for $10 \mathrm{~min}$, stirred with connective tissue and the concentrations of nucleotides ( \pm SE) released into the supernatant determined. The supernatants from the buffer treated specimens contained 16.4 \pm 2.6 m $\mu$ moles of ADP and $10.9 \pm 2.0$ m $\mu$ moles of $\mathrm{ATP} / 10^{\circ}$ platelets; the values in the aspirin treated specimens were $4.7 \pm 1.2$ and $3.4 \pm 0.5$ m $\mu$ moles, respectively.

Platelet surface charge. Hugues and Lapiere have reported that promethazine inhibited the adhesion of platelets to connective tissue, similar to the findings reported herein with aspirin, and suggested an alteration in platelet-surface charge as a possible mechanism (27). The effect of aspirin on detectable platelet surface charge was studied by measurements of electrophoretic mobility. Citrated PRP was incubated with $1 / 20$ volume of either imidazole buffer, aspirin, or sodium salicylate (final salicylate concentration $0.5 \mathrm{mmole} / \mathrm{liter}$ ) for $10 \mathrm{~min}$ and then diluted $1: 20$ in either buffer 
or in buffer containing $0.5 \mathrm{mmole} / \mathrm{liter}$ of the same salicylate used for the incubation. Specific resistance of the suspension and the timed migration of 20 platelets was determined and the mobility calculated as described in methods. As seen in Table $\mathrm{V}$, incubation of PRP with aspirin had no effect on platelet electrophoretic mobility.

Plasma ADPase. ADP is rapidly destroyed by plasma (ADPase) (28). This effect was not enhanced, in vitro, by the presence of aspirin, as shown in Fig. 5.

Other experiments. Aspirin has no effect on connective tissue itself. Connective tissue suspension was incubated with platelet-poor plasma containing $0.25 \mathrm{~mm}$ aspirin or buffer and an aliquot of the mixture was then stirred with citrated PRP. The conditions were such that the amount of aspirin transferred with the incubation mixture resulted in a concentration of only $0.01 \mathrm{~mm}$ in the PRP, while the final connective tissue concentration was the same as in previous experiments. The results showed that previous incubation of connective tissue with $0.25 \mathrm{~mm}$ aspirin did not inhibit its ability to release platelet ADP when it was subsequently added to $\mathrm{PRP}$, in contrast to the inhibi-

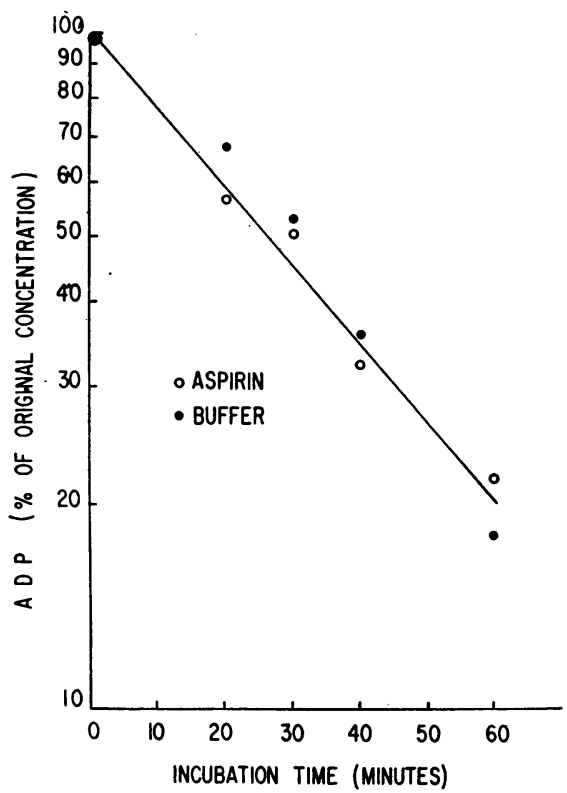

FIgURE 5 Effect of aspirin on plasma ADPase activity. Citrated platelet-poor plasma, containing $1 / 20$ volume of ADP in a final concentration of $15 \mu$ moles/liter, was incubated with $1 / 20$ volume of either buffer or aspirin (final concentration $0.5 \mathrm{mmole} /$ liter) at $37^{\circ} \mathrm{C}$.
TABLE V

Effect of Salicylates on Platelet Electrophoretic Mobility*

\begin{tabular}{lcccc}
\hline & \multicolumn{4}{c}{ Mobility } \\
\cline { 2 - 4 } Drug Subject. & I & II & III & Mean \pm SE \\
\hline \multicolumn{4}{c}{$10^{-4} \cdot\left[\mathrm{cm}^{2} \sec ^{-1}\right.$} & $\left.v^{-1}\right]$ \\
Buffer & -1.005 & -1.034 & -0.907 & $-0.982 \pm 0.037$ \\
Aspirin & -1.008 & -1.054 & -0.870 & $-0.977 \pm 0.054$ \\
Na salicylate & -0.992 & -1.036 & -0.910 & $-0.979 \pm 0.036$ \\
\hline
\end{tabular}

* Salicylate ( 5 mmoles/liter) or buffer was incubated, in duplicate, with citrated PRP for $10 \mathrm{~min}$. The average of the two values are shown.

tory effect observed when this concentration of aspirin was added directly to the PRP.

Incubation of citrated PRP with connective tissue, without stirring, for $20 \mathrm{~min}$ at $37^{\circ} \mathrm{C}$ resulted in a decrease of platelet ATP which was not inhibited by previous incubation with aspirin.

When aspirin was added to PRP, inhibition of platelet ADP release was achieved after only $1 \mathrm{~min}$ of incubation at ambient temperature and was not enhanced by further incubation for 10 and $30 \mathrm{~min}$. The temperature dependence of the effect was studied by incubating PRP from four normal subjects with either buffer or aspirin at 4,24 , or $37^{\circ} \mathrm{C}$, bringing the mixture to ambient temperature, and then stirring an aliquot with connective tissue. When compared with the results obtained for the buffer control, ADP release was decreased by $50 \%$ at $4^{\circ} \mathrm{C}, 40 \%$ at $24^{\circ} \mathrm{C}$, and $60 \%$ at $37^{\circ} \mathrm{C}$.

Finally, in contrast to the inhibitory effect produced by adding aspirin to platelet-rich plasma, such an effect could not be demonstrated with a suspension of washed platelets. When the platelets in citrated PRP were washed twice at $20^{\circ} \mathrm{C}$ with buffer containing $0.1 \%$ EDTA, once more with buffer alone, suspended in the same buffer, and then stirred with connective tissue, platelet aggregation did not occur, although ADP was released. This release was not inhibited by previous incubation of the suspension with aspirin.

\section{DISCUSSION}

Recent studies indicate that when platelets are stirred with washed connective tissue fragments or collagen, adenosine diphosphate is released $(29,30)$ which results in platelet aggregation (31). As in previous studies, in which the effects were noted after several days of a larger dose 
(14), ingestion of a single $1.5 \mathrm{~g}$ dose of aspirin resulted in impaired aggregation by connective tissue and was associated with a decreased release of platelet ADP. The aspirin-induced platelet defect is pharmacological and has now been observed in 16 out of 18 normal subjects studied. The inhibition of ADP release is also reflected in the results obtained with $\mathrm{ADP}$ and epinephrine. When these agents are stirred with platelet-rich plasma at $37^{\circ} \mathrm{C}$, aggregation occurs in two phases : the first is caused by the substance added, the second is due to release of intrinsic platelet ADP (25). Previous incubation of PRP with aspirin inhibits the second wave of aggregation, but has no effect on the first, similar to the findings reported by Zucker and Peterson after aspirin ingestion (26). The findings are not inconsistent with our previous report that platelet aggregation by ADP at ambient temperature is unaffected by aspirin ingestion (14) since only primary aggregation occurs at this temperature. The maximal inhibition of platelet ADP release was achieved with an aspirin concentration of $0.5 \mathrm{mmole} / \mathrm{liter}$ $(0.045 \mathrm{mg} / \mathrm{ml})$, the approximate salicylate concentration obtained by ingesting a solution containing $640 \mathrm{mg}$ of aspirin (32). The conditions used to study platelet aggregation and ADP release are necessarily artificial and it may not be proper to extrapolate from the results obtained with a connective tissue suspension to conditions which occur in vivo. Nevertheless, Packham and coworkers have demonstrated (33) that in rabbits treated with phenylbutazone, a drug whose effect on platelets appears to be similar to that of aspirin (34), the arrest of bleeding in transected mesenteric vessels is markedly retarded and it seems reasonable to conclude that the prolongation of the bleeding time in man after aspirin ingestion is related to the platelet abnormalities described. The average salicylate concentration of $0.113 \mathrm{mg} / \mathrm{ml}$ of serum achieved in the six subjects described herein after ingesting $1.5 \mathrm{~g}$ of powdered aspirin may well have been in excess of the amount required to impair both platelet function and prolong the bleeding time. It should be emphasized that the increase in the Ivy bleeding time of $1.75 \mathrm{~min}$, while statistically significant when compared with the contol group, was modest and does not necessarily indicate a clinically significant impairment of hemostasis in these normal individuals. It would be of interest to know if aspirin ingestion was associated with an increased amount of bleeding during and after tonsillectomy, as well as other surgical procedures.

The findings that sodium salicylate did not inhibit platelet adhesion to connective tissue, platelet aggregation, or ADP release is consistent with its failure to prolong the bleeding time and lends further support to the hypothesis that the prolongation seen after aspirin ingestion is due to inhibition of these reactions. The results may also explain the findings in previous reports that gastrointestinal bleeding occurs more frequently and to a significantly greater degree after ingesting aspirin than after sodium salicylate $(3,10)$, although the local effects on the gastrointestinal tract would require another explanation. Other differences in the effects of the two drugs have been reported. Aspirin, unlike sodium salicylate, abolishes the antiinflammatory response produced by the topical application of thurfyl nitrate (35) and has been reported to be a better analgesic (36) and antipyretic agent (37). Seed has suggested that the superiority of aspirin may be attributed to the fact that, because of its higher $\mathrm{pK}$, the greater concentration of the unionized form at $\mathrm{pH} 7.4$ facilitates a more rapid diffusion into the cell (37) since it is only this moiety which enters the cell (32). The statement assumes that the effect of salicylates occurs intracellularly, rather than at the plasma membrane. Moreover, it does not take into consideration the fact that unionized salicylate diffuses more rapidly than unionized acetylsalicylate, possibly due to its greater lipid partition coefficient (32). Thus, at a $\mathrm{pH}$ of 5 , salicylate diffuses more rapidly across the intestinal mucosa

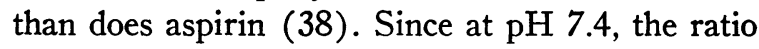
(3.164) of unionized salicylate ( $\mathrm{pK} 3.0$ ) to unionized acetylsalicylate ( $\mathrm{pK} 3.5$ ) is substantially the same as the ratio (3.098) at $\mathrm{pH} 5$, at equimolar concentrations of the respective acids, it is unlikely that aspirin diffuses more rapidly into the cell than sodium salicylate. Another possible explanation for the lesser activity of sodium salicylate is its much tighter binding by plasma albumin, resulting in lower tissue concentrations (39). The data presented by Lester, Lolli, and Greenberg permit one to construct a graph from which the per cent of unbound salicylate present in plasma may be determined from the concentra- 
tion of total salicylate (39). Thus, with a total salicylate concentration of $1.67 \mathrm{mmoles} / \mathrm{liter}, 0.45$ mmole/liter would be unbound and, from data also presented (39), this same concentration of free acetylsalicylate would also be obtained with a $0.67 \mathrm{mmole} /$ liter total concentration of aspirin. When these two concentrations, producing equivalent amounts of the unbound form, are identified in Fig. 1, it is seen that the inhibitory effect of aspirin on the release of platelet ADP is still greater than that of sodium salicylate. The findings in the present study do not preclude the possibility that the prolonged use of sodium salicylate might result in abnormalities that were not detected in the "single dose" study reported here. However, this possibility was not explored in the present study.

The term "released ADP" has been used in this study to denote the amount of ADP detected in the ambient plasma after platelet-rich plasma has been stirred with connective tissue, reflecting the available platelet ADP, its diffusability, through an altered membrane, and its destruction by plasma ADPase. The decreased values measured after ingesting aspirin or, in vitro, after incubating it with PRP, suggest several possible mechanisms, some of which appear to have been ruled out by these studies. Aspirin does not alter the amount of available ADP or, as also reported previously, ATP (14). Although aspirin uncouples oxidative phosphorylation in many in vitro cell systems (40), thereby reducing available ATP, it has been difficult to demonstate this in whole animal experiments (14). Aspirin ingestion does not change the concentration of the total $\left(\mathrm{Mg}^{++}, \mathrm{Na}^{+}, \mathrm{K}^{+}\right.$dependent) ATPase measured in osmotically lysed platelet membranes (14) and there is no evidence that its presence in plasma enhances plasma ADPase activity.

The available evidence suggests that aspirin does, in fact, inhibit the release of ADP from the platelet into the ambient fluid, perhaps reflecting a more general inhibitory effect of this drug on membrane permeability as indicated by a similar inhibition of the release of platelet ATP. Miller and Smith have reported that aspirin stabilizes rat liver lysosomes and inhibits the release of their hydrolytic enzymes (42). Gander, Chaffee, and Goodale reported that administration of high doses of sodium salicylate inhibited the release of leuko- cyte pyrogen (43) and Smith and Humphrey concluded from their studies that the antiinflammatory effect of salicylates was due, in part, to a decrease in capillary permeability (44). The ability of aspirin to inhibit platelet ADP release after oral administration in man is similar to the effect which Evans, Packham, Nishizawa, and Mustard have reported after administration to rabbits (45) and which Mustard and coworkers have demonstrated for a variety of antiinflammatory agents $(33,34)$. Mills and Roberts have recently added to the drugs which may inhibit platelet ADP release (46). They found that secondary aggregation by epinephrine and ADP were inhibited by chlorpromazine, diphenhydramine, promethazine, and desmethylimipramine, drugs which are known to have a stabilizing action on biological membranes (47-50).

The mechanism by which these drugs inhibit the release of platelet ADP remains to be determined. Like promethazine (27) aspirin inhibits the adhesion of platelets to connective tissue without altering the detectable platelet surface charge. It is unlikely, however, that a decrease in adhesion, or binding, would explain the results obtained with ADP or epinephrine, since Salzman, Chambers, and Neri have shown that primary aggregation, which is not effected by these drugs, may occur without significant binding of ADP (51). By whatever mechanism, aspirin appears to produce a rapid platelet defect which persists when salicylate is no longer detectable in the blood and does not completely disappear until 4-7 days after ingestion. This period corresponds roughly to the platelet life span and suggests that aspirin produces an irreversible defect in the platelet.

Finally, the ability of drugs such as aspirin to interfere with the hemostatic properties of platelets suggests that they may also inhibit the formation of platelet thrombii, a primary event in the formation of an arterial thrombus.

\section{ADDENDUM}

After this article was submitted for publication, O'Brien published the results of experiments in man (52) which confirmed the previous report of the authors on the inhibitory effect of aspirin ingestion on the platelet/connective tissue reaction (14). His studies also indicate that after ingestion of a single dose of aspirin, the epinephrineinduced secondary wave of platelet aggregation disappears for 1-5 days or longer while ingestion of sodium salicylate 
has no effect, results similar to the findings in the present study on the effects of salicylate ingestion on the release of platelet ADP by connective tissue.

\section{ACKNOWLEDGMENTS}

The authors wish to express their appreciation to $\mathrm{Mr}$. John Rogers, Mrs. Sadie Chu, Miss Carol Ehrlich, and Mrs. Ngukoy Liu for their expert technical assistance.

The paper was supported in part by U. S. Public Health Service General Research Support Grant FR 05500 and contract PH 43-67-1359, grants HE 10905 from the National Heart Institute and AM 04434 from the National Institute of Arthritis and Metabolic Diseases, and the Albert A. List, Frederick Machlin, and Anna Ruth Lowenburg Fund.

\section{REFERENCES}

1. Stubbé, L. Th. F. L. 1958. Occult blood in faeces after administration of aspirin. Brit. Med. J. 2: 1062.

2. Holt, P. R., 1960. Measurement of gastrointestinal blood loss in subjects taking aspirin. J. Lab. Clin. Med. 56: 717 .

3. Scott, J. T., I. H. Porter, S. M. Lewis, and A. St. J. Dixon. 1961. Studies of gastrointestinal bleeding caused by corticosteroids, salicylates and other analgesics. Quart. J. Med. 30: 167.

4. Muir, A. 1963. Salicylates and the gastrointestinal tract. In Salicylates, an International Symposium. A. St. J. Dixon, M. J. H. Smith, B. K. Martin, and P. H. N. Wood, editors. J \& A Churchill, Ltd., London. 187.

5. Stubbé, L. Th. F. L. The role of aspirin in causing iron-deficiency anemia. In Salicylates, an International Symposium. A. St. J. Dixon, M. J. Smith, B. K. Martin, and P. H. N. Wood, editors. J \& A Churchill, Ltd., London. 236.

6. Quick, A. J., and L. Clesceri. 1960. Influence of acetylsalicylic acid and salicylamide on the coagulation of blood. J. Pharmacol. Exptl. Therap. 128: 95.

7. Meyer, O. O., and B. Howard. 1943. Production of hypoprothrombinemia and hypocoagulability of the blood with salicylates. Proc. Soc. Exptl. Biol. Med. 53: 234 .

8. Douthwaite, A. H., and G. A. M. Lintott. 1938. Gastroscopic observation of the effect of aspirin and certain substances on the stomach. Lancet. 2: 1222.

9. Smith, M. J. H. 1966. Gastrointestinal bleeding. In The Salicylates, a Critical Bibliographic Review. M. J. H. Smith and P. K. Smith, editors. Interscience Publishers, Inc., New York. 235.

10. Grossman, M. I., K. K. Matsumoto, and R. J. Lichter. 1961. Fecal blood loss produced by oral and intravenous administration of various salicylates. Gastroenterology. 40: 383 .

11. Blatrix, C. 1963. Allongement du temps de saignement sous l'influence de certain médicaments. Nouvelle Rev. Franc. Hematol. 3: 346.

12. Quick, A. J. 1967. Salicylates and bleeding: the aspirin tolerance test. Am. J. Med. Sci. 252: 265.
13. Quick, A. J. 1967. The Minot-von Willebrand syndrome. Am. J. Med. Sci. 253: 520.

14. Weiss, H. J., and L. M. Aledort. 1967. Impaired platelet/connective tissue reaction in man after aspirin ingestion. Lancet. 2. 495.

15. Weiss, H. J. 1967. Platelet aggregation, adhesion and adenosine diphosphate release in thrombopathia (platelet factor 3 deficiency). A comparison with Glanzmann's thrombasthenia and von Willebrand's disease. Am. J. Med. 43: 570.

16. Hardisty, R. M., and R. A. Hutton. 1967. Bleeding tenedency associated with "new" abnormality of platelet behavior. Lancet. 1: 983.

17. Weiss, H. J. 1967. The effect of clinical dextran on platelet aggregation, adhesion and ADP release in man: in vivo and in vitro studies. J. Lab. Clin. Med. 69: 37 .

18. Zucker, M. B., and J. Borrelli. 1962. Platelet clumping produced by connective tissue suspensions and by collagen. Proc. Soc. Exptl. Biol. Med. 109: 779.

19. Hutterer, F., and E. J. Singer. 1960. A modified method for hydroxyproline determination. Anal. Chem. 32: 556.

20. Lowry, O. H., N. J. Rosebrough, A. L. Farr, and R. J. Fandall. 1951. Protein measurement with the Folin phenol reagent. J. Biol. Chem. 193: 265.

21. Born, G. V. R., and M. J. Cross. 1963. The aggregation of blood platelets. J. Physiol. 168: 178.

22. Aledort, L. M., R. I. Weed, and S. B. Troup. 1966. Ionic effects of firefly biolumenescence assay of red blood cell ATP. Anal. Biochem. 17: 268.

23. Brodie, B. B., S. Udenfriend, and A. F. Coburn. 1944. The determination of salicylic acid in plasma. J. Pharmacol. Exptl. Therap. 80: 114.

24. Brownlee, K. A. 1965. Statistical Theory and Methodology in Science and Engineering. John Wiley \& Sons, Inc., New York. 2nd edition. 498.

25. MacMillan, D. C. 1966. Secondary clumping effect in human citrated platelet rich plasma produced by adenosine diphosphate and adrenaline. Nature. 211: 140.

26. Zucker, M. B., and J. Peterson. 1968. Inhibition of adenosine diphosphate-induced secondary aggregation and other platelet functions by acetylsalicylic acid ingestion. Proc. Soc. Exptl. Biol. Med. 127 : 547.

27. Hugues, J., and C. M. Lapiere. 1964. Nouvelles recherches sur l'accolement des plaquettes aux fibres de collagene. Thromb. Diath. Haemorrhag. 11: 327.

28. Odegaard, A. E., B. A. Skalhegg, and A. J. Hellem. 1964. Investigations on adenosine diphosphate (ADP) induced platelet adhesiveness in vitro. Part III. The inactivation of ADP in plasma. Thromb. Diath. Haemorrhag. 11: 317.

29. Spaet, T. H., and M. B. Zucker. 1964. Mechanism of platelet plug formation and role of adenosine diphosphate. Am. J. Physiol. 206: 1267.

30. Hovig, T. 1963. Release of a platelet aggregating substance (adenosine diphosphate) from rabbit blood platelets induced by saline "extract" of tendons. Thromb. Diath. Haemorrhag. 9: 264. 
31. Gaarder, A., J. Jonsen, S. Laland, A. Hellem, and P. A. Owren. 1961. Adenosine diphosphate in red cells as a factor in the adhesiveness of blood platelets. Nature. 192: 531.

32. Levy, G., and J. R. Leonards. 1966. Absorption, metabolism and excretion of salicylates. In The Salicylates, a Critical Biographical Review. M. J. H. Smith and P. K. Smith, editors. Interscience Publishers, Inc., New York. 5.

33. Packham, M. A., E. S. Warrior, M. F. Glynn, A. S. Senyi, and J. F. Mustard. 1967. Alteration of the response of platelets to surface stimuli by pyrazole compounds. J. Exptl. Med. 126: 171.

34. Mustard, J. F., M. F. Glynn, E. E. Nishizawa, and M. A. Packham. 1967. Platelet surface interactions: relationship to thrombosis and hemostasis. Federation Proc. 26: 106.

35. Adams, S. S., and R. Cobb. 1963. The effect of salicylates and related compounds on erythema in the guinea pig and man. In Salicylates, an International Symposium. A. St. J. Dixon, M. J. H. Smith, B. K. Martin, and P. H. N. Wood, editors. J \& A Churchill, Ltd., London. 127.

36. Levy, G. 1965. Aspirin absorption rate and analgesic effect. Anesthesie Analgesia. 44: 837.

37. Seed, J. C. 1965. A clinical comparison of the antipyretic potency of aspirin and sodium salicylate. Clin. Pharmacol. Therap. 6: 354.

38. Hogben, C. A. M., D. J. Tocco, B. B. Brodie, and L. S. Schanker. 1959. On the mechanism of intestinal absorption of drugs. J. Pharmacol. Exptl. Therap. 125: 275 .

39. Lester, D., G. Lolli, and L. A. Greenberg. 1946. The fate of acetylsalicylic acid. J. Pharmacol. Exptl. Therap. $87: 329$.

40. Brody, T. M. 1956. Action of sodium salicylate and related compounds on tissue metabolism in vitro. $J$. Pharmacol. Exptl. Therap. 117: 39.

41. Smith, M. J. H. 1966. Metabolic effects of salicylates. In The Salicylates, a Critical Biographical Review.
M. J. H. Smith and P. K. Smith, editors. Interscience Publishers, Inc., New York. 49.

42. Miller, W. S., and J. G. Smith, 1966. Effect of acetylsalicylic acid on lysosomes. Proc. Soc. Exptl. Biol. Med. 122: 634.

43. Gander, G. W., J. Chaffee, and F. Goodale. 1967. Studies on the antipyretic action of salicylates. Proc. Soc. Exptl. Biol. Med. 126: 205.

44. Smith, W., and J. H. Humphrey. 1949. The effect of sodium salicylate upon hypersensitivity reactions. Brit. J. Exptl. Pathol. 30: 560.

45. Evans, G., M. A. Packham, E. E. Nishizawa, and J. F. Mustard. 1967. The effect of the plateletcollagen reaction and blood coagulation on hemostasis. J. Clin. Invest. 46: 1053. (Abstr.)

46. Mills, D. C. B., and G. C. K. Roberts. 1967. Membrane active drugs and the aggregation of human blood platelets. Nature. 213: 35 .

47. Judah, J. D., K. Ahmed, and A. E. M. McLean. 1964 Possible role of ion shifts in liver injury. In Ciba Foundation Symposium on Cellular Injury. A. V. S. de Rueck and J. Knight, editors. Little, Brown and Company, Boston. 187.

48. Rees, K. R. 1962. Cellular injury by drugs. In Ciba Foundation Symposium on Enzymes and Drug Action. J. L. Mongar and A. V. S. de Reuck, editors. Little, Brown and Company, Boston. 344.

49. Freeman, A. R., and M. A. Spirtes. 1963. Effects of chlorpromazine on biological membranes-II Chlorpromazine-induced changes in human erythrocytes. Biochem. Pharmacol. 12: 47.

50. Abood, L. G., H. Kimizuka, G. Rogeness, and J. H. Biel. 1963. Some antidepressant drugs and their mechanism of action on excitable membranes. Ann. N. Y. Acad. Sci. 107: 1139.

51. Salzman, E. W., D. A. Chambers, and L. L. Neri. 1966. Incorporation of labaled neucleotides and aggregation of human blood platelets. Thromb. Diath. Haemorrhag. 15: 52.

52. O'Brien, J. R. 1968. Effects of salicylates on human platelets. Lancet. 1 : 779. 